\title{
水スラリーのコイル内流動と熱伝達特性 \\ Flow and Heat transfer Characteristic of Ice Slurries in a Coil
}

正 堀部 明彦 (岡山大院) 正 春木 直人（岡山大院） ○学 田中 邦明（岡山大院）

Akihiko Horibe , Naoto Haruki and Kuniaki Tanaka

Okayama University, 3-1-1 Tsushima-naka, Kita-ku, Okayama

This paper presents the effect of some factors on the flow and heat transfer characteristic of ice slurry in a coil. The ice slurry is solid-liquid fluid which consists of ice particles and water. The experiments were carried out under various parameters of ice slurry velocity, ice packing factor of ice slurry, and heat flux. As a result, it was found that interaction between latent heat of ice and restraint of secondary flow has an effect on the flow and heat transfer characteristic of ice slurry in a coil.

Key Words: Ice slurry, Coil, Heat transfer, Forced convection

\section{1. 緒言}

近年，電力消費量功民生を中心に増加の一途をたじって おり,さらに電力需要には季節や昼夜閒で大きな差がある。 そのため, 空調機器の省エネルギー化や昼夜の電力負荷の 平準化が求められている。 そこで現在、安価な夜閒電力を 利用して製水し、その水を昼間の空調に利用する氷蓄熱シ ステムが注目されている。 その中でも水と水の固液二相流 である水スラリーを利用したものは、水の融解潜熱による 高い熱輸送能力を持ち，更なる設備の小型化，省エネルギ 一化が可能となる(1). しかし，水スラリーを用いた場合， 水粒子の凝集による管閉塞や水粒子と管壁との摩擦による 圧力損失の増大などの問題が生じる. 本研究は, 平均流速 $u_{s}$, 水の体積分率 $I P F$ (IPF : Ice Packing Factorの略), 熱 流束 $q$ 变変化させた場合において, 水スラリーのコイル管内 流動および熱伝達特性に及ぼす要因について実験的に検討 するものである.

\section{2. 実験装置および方法}

\section{$2-1$ 実験装置}

実験装置は Fig.1 のように氷スラリー混合槽，ボルテッ クスポンプ, コイル状試験部，電磁流量計等からなり，さ らに水スラリーの流動状態を視誌するためコイル状試験部 の前後に可視化試験部を設置している。なおコイル状試験 部の入口出口付近には直接通電用の電極を設けている。 イル状試験部は内径 $14 \mathrm{~mm}$, 外径 $16 \mathrm{~mm}$, 曲率半径比 $R / r=20$, ステンレス製で 6 回巻きコイル状の円管である. 可視化試 験部は, 軸力向長さ $300 \mathrm{~mm}$, 内径 $14.2 \mathrm{~mm}$ のアクリル製 円管である，温度測定のために，コイル状試験部に $\mathrm{T}$ 型熱 電対を入口から，0，10，30，50，90，120，180，360，720， $1080,1440,1800,2160^{\circ}$ の位置のそれぞれ外壁の上下内 外に取り付けた，同時に圧力を測定するためにコイル状試 験部の前後に圧力タップを設置し差圧計に接続している. 実験装置は周囲への熱損头を防ぐためグラスウールでの断 熱し，さらに室温を $2^{\circ} \mathrm{C} に$ 設定した恒温恒湿室内にて実験 を行った。

\section{2-2 実験方法}

本实験では，実験パラメーターとして，水スラリーの流 速 $u_{s}$, 試験部入口氷充填率であるIPF $F_{i n}$, 熱流束 $q$ を選定して おり，その範囲をTable 1 に示す。 なお，水粒子の平均径 $d_{p}$ は $0.8 \mathrm{~mm}$ である。実験では恒温恒湿室内にて，混合槽内を 所定のIPFにし，流速が所定の条件に安定したところで， 温度変化，圧力損失などを計測し，水スラリーの流動状態 について検討した，試験部は直接通電により等熱流束加熱 して,水スラリーと管壁の温度を測定し熱伝達率を求めた。

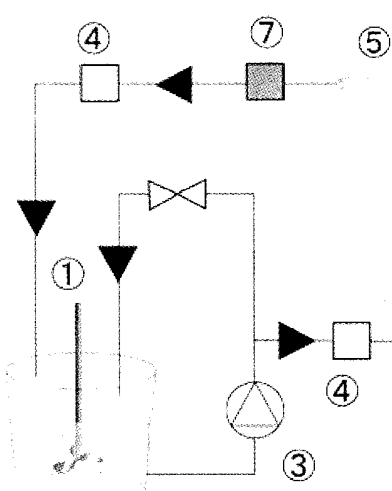

(2)
(1) Mixer
(2)Tank
(5) Visible section
(3) Vortex pump
(6) Test section
(4)IPF sensor
(7) Magnetic flow meter
(8)Differencial pressure gauge

Fig.1 Outline figure of experimental equipment

Table 1 Several parameter of the experiment

\begin{tabular}{|c|c|c|}
\hline$u_{s}(\mathrm{~m} / \mathrm{s})$ & $I P F(\%)$ & $q\left(\mathrm{~kW} / \mathrm{m}^{2}\right)$ \\
\hline $0.8 \sim 2.0$ & $0 \sim 20$ & $5.5 \cdot 10.5 \cdot 15.5$ \\
\hline
\end{tabular}

\section{3. 実験結果}

3-1 圧力損失

Fig.2 沙試験部の圧力損失を示し, グラフの横軸は水ス ラリーの平均流速 $u_{s}$ を, 縦軸は試験部全体での圧力損失を 測定区間長さLで除した值 $(\Delta P / L)$ である. 本実験における実 験条件は曲率半径比 $R / r=20$, 熱流束 $q=10.5 \mathrm{~kW} / \mathrm{m}^{2}$ であり, 過去の実験(2)において使用した曲管の場合の結果も並記し ている.

その結果，水のみを流動させた場合には，コイル管では 曲管に比心゙単位長さあたりの圧力損失が増大している. 曲 管を流動するときに生じる二次流れは曲管の入口からおよ そ $90^{\circ}$ の地点で発達しきるため, $180^{\circ}$ の曲管では発達 した二次流れの影響を受けているのは試験部の約半分の区 閐だけと考えられる。しかし、コイル管では試験部の約 95\%の区閒において発達した二次流れの影響を受けてい る(3). そのため, 二次流れによる管内の旋回流の影響によ って管内流れが乱され，より大きな圧力損失になったと考 えられる。 
また，コイル管においてIPF $F_{\text {in }}=10 \%$ \%で，いずれの流速 においても，水スラリーと水の単位長さあたりの圧力損失 に大きな差は確認できなかった，曲管においては管壁と水 粒子の衝突・摺動による摩擦力の増加があり，一方で管内 の水粒子が曲管内での二次流れを抑制する作用が働くこと が考えられる。そのため，コイル管に掠いてもこの二つの 作用により圧力損失の増加と抑制とが相互に作用すると考 えられる。その結果，いずれの流速でも二つの作用の影響 が互いに打ち消しあい，水スラリーと水の単位長さあたり の圧力損失に大きな違いは確認できなかったと推察できる.

\section{3-2 熱伝達率}

Fig.3-1，3-2 は横軸を試験部入口からの角度 $\theta$ とし，縦軸 は局所熱伝達率 $\alpha_{\theta}$ を示したものである. Fig.3-1 が試験部 上 $(\triangle)$ 下 $(\nabla)$ を, Fig.3-2 が試験部内 $(\bigcirc)$ 外 $(\square)$ における局所 熱伝達率を示す. 実験条件は曲率半径比 $R / r=20$, 水スラリ 一流速 $u_{s}=1.0,2.0 \mathrm{~m} / \mathrm{s}$, 試験部入口氷充填率 $I P F_{i n}=5,10 \%$, 等熱流束 $q=15.5 \mathrm{~kW} / \mathrm{m}^{2}$ である.

Fig.3-1，3-2 より $u_{s}=1.0 \mathrm{~m} / \mathrm{s}$ において試験部上部・外側 ではIPF $F_{\text {in }}=5 \%$ より IPF $F_{\text {in }}=10 \%$ の方が試験部後半にかけて 若干高い熱伝達率を示していることがわかる。この時， $I P F_{\text {in }}=5 \%$ の場合には $\theta=1150^{\circ}$ 地点付近で水スラリー中の 水が全て融解するが，IPF 存在する，そのため，氷粒子の浮力の影響と曲管流れにお ける遠心力の影響により水粒子が試験部上部・外側に偏在 しその部位では水の融解潜熱が影響したためだと推察でき

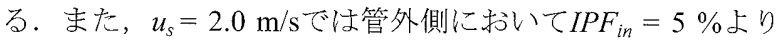
$I P F_{\text {in }}=10 \%$ の方が試験部後半にか子て若干高い熱伝達率 を示していることがわかる。これは，試験部後半にかけて 小さくなったクラスターは，管内流れの主流の慣性力が氷 粒子の浮力の影響よりも大きいことと遠心力の影響によっ て氷粒子が管外側のみに偏在し流動するが, $I P F_{\text {in }}=10 \%$ の 方が管外側に㧍ける管壁と氷粒子の接触面積が大きいため にIPF $F_{\text {in }}=5 \%$ よりも多くの水の融解潜熱を得ているものと 推察できる。しかし，管上部では熱伝達率の变化はほとん ど見られなくなった。これは，試験部内の滞留時間が減少 するため，この条件における水粒子の融解梳試験部全体で 3〜 4\%程度と $u_{s}=1.0 \mathrm{~m} / \mathrm{s}$ の場合に比べてあまりなく，融解 潜熱による熱伝達率増加の効果が減少したことと，氷粒子 が管外側へ偏在し流動するためと考えられる.

一方，試験部の下部および内側では，いずれの流速にお いてもIPFを変化させた場合に熱伝達にはほとんど差がな いことがわかる，先に記したように試験部上部・外側の熱 伝達の結果から，試験部入口ではクラスターを形成し流路 断面全体を流動していた水スラリーが，加熱されることに よってクラスターが小さくなり，氷粒子の浮力と曲管流れ における遠心力の影響によって管上部および外側に偏在す る. そのために管下部および内側では水の融解潜熱を得る ことが出来ず，下部および内側では差が生じなかったと推 察できる.

\section{4. 参考文献}

（1）大平昭義，冷空論，21-4 (2004), 285

(2) 堀部明彦ら，第 45 回日本伝熱シンポジウム講演論文 集，Vol. II + III，(2008)，617

(3) Wael Ibrahim Ahmed Aly，岡山大学大学院博士学位 論文 (2007)

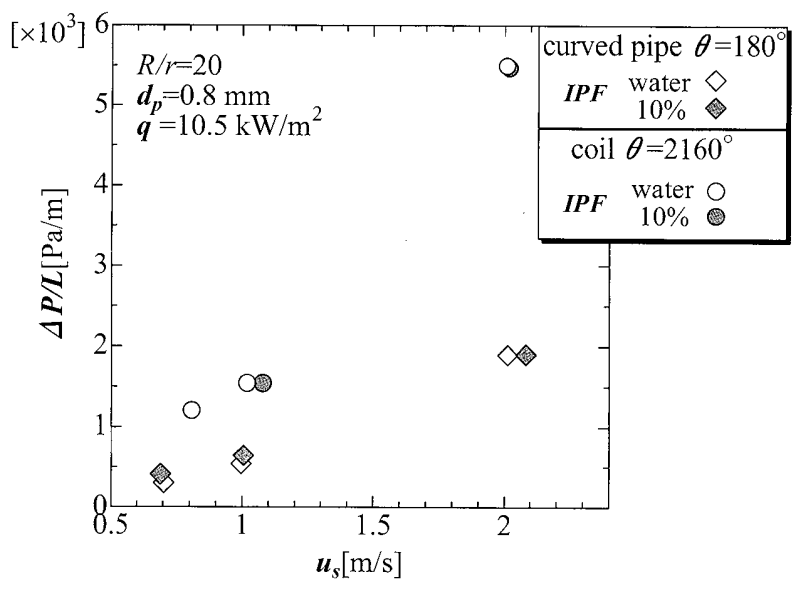

Fig.2 Relationship between Local pressure loss and Mean velocity

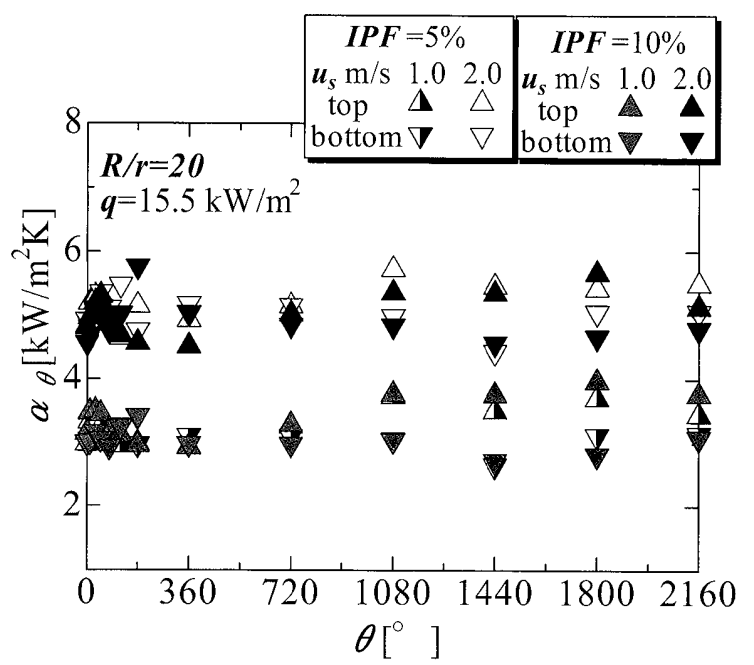

Fig.3-1 Relationship between $\alpha$ and $\theta$ (top \& bottom)

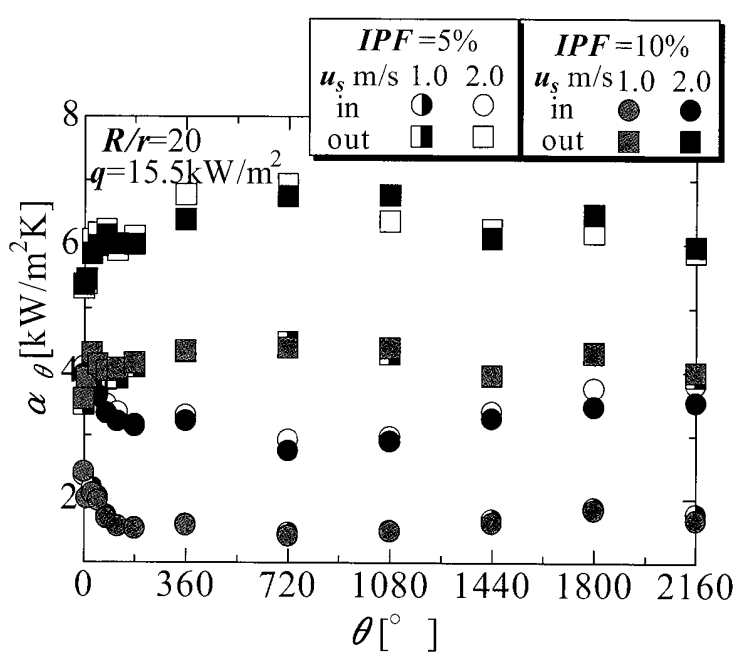

Fig.3-2 Relationship between $\alpha$ and $\theta \quad$ (in \& out) 